\title{
Introduction: the Opportunities of the Four Pillars' Strategy*
}

\author{
by Orio Giarini**
}

\section{The chances of an "aging" population}

Thanks to the positive effects of an industrial revolution that we have experienced for over two centuries, we can now all benefit in the industrialized countries of a life expectancy, at 60 , which is in the average getting closer to 20 years.

In other words, we have at 60 a life expectancy which at the beginning of the industrial revolution was such for those still in their twenties.

In addition, we can expect that about 80 to 90 per cent of our life expectancy at 60 , will be spent in reasonably good health with quite a large margin for active endeavours of all kinds.

We cannot call this situation a problem, as some do, but rather a chance.

And we cannot even complain about the fact that other parts of the world are "younger": if India and China for instance are going to benefit from our same economic and social developments, they will also, in thirty to forty years' time, have an extremely large population of people over 60 years.

We must also remember that, given the present trends, we should reach in the world a population of one billion people over sixty around the year 2020 .

It is in Europe and in the other industrialized parts of the world that we have right now plenty of time and possibilities to face the development of a society which has enormously extended both the quantity and the quality of life at an unprecedented level.

This is probably one of the most important historical and sociological changes ever: it depends on our imagination and will to transform the "problems" into "opportunities".

\section{The basic change in the economic environment}

Progression of economic wealth depends today, be it in the agricultural, in the industrial or in the traditional services sector, essentially on service functions.

* Text presented at the International Conference of EFMA on "Banking and Insurance", Madrid, November 10, 1989.

** Secretary General and Director of the Geneva Association and Professor of Service Economics at the Graduate Institute of European Studies, University of Geneva. 
In fact, we do not live anymore in an "industrial society" but in a "service economy" in which all countries tend to have up to 80 per cent of their working force active in a service function.

Such service functions are not anymore of the "pre-industrial" type, but have essentially a "post-industrial" connotation. The great paradox of the industrial revolution is that the more technology is advancing and developing its performances, the more the economic machinery depends on larger and diversified service functions such as: research and development, financing, risk management and insurance, maintenance, distribution, safety, waste control, education etc.

Whereas in the traditional industrial economy services were often considered as nonproductive and in any case as secondary to the manufacturing industrial endeavour, in the contemporary economy, services have become a key factor in the investment, production and distribution process or, as the economists would say, services are part of the production function. More than that: they absorb a relatively higher portion of resources in all fields.

\section{The employment outlook}

The development of services as a key factor of the modern economy has completely changed the quality of jobs available. See on this the article of Luigi Frey.

On the one side, we can observe that higher skills and higher salaries go together in the service sector. As a consequence the need for adequate educational programs grows.

On the other side, the very nature of service activities has produced an ever increasing number of job possibilities of a flexible nature. Rigidity was the typical characteristic of an older manufacturing production chain. On the contrary, several forms of flexible work systems concerning both time and space and way of organization are constantly being developed. ${ }^{1}$ The study of Geneviève Reday-Mulvey provides a lot of evidence.

In this great period of change, the great questions concern:

- The problems created by frictional unemployment, encompassing essentially adaptation from old qualifications for employment to new ones.

- Women are entering the working force at growing rate: the Northern European countries have already a rate of women's employment which is very close to that for men. The $50 \%$ level of women employment as compared to men has just been crossed in the United States last year, whereas it is of $60 \%$ in the UK.

- The overall increase of part-time jobs, which is not anymore of the old "industrial" type (associated to the lower and very often unprotected level of workers and employees): part-time jobs are more and more related to the utilization of qualified experiences which, for a series of reasons, an active person cannot or will not use for a full-time job. ${ }^{1}$ The study by Lei Delsen provides an analysis of part-time retirement in Europe.

\footnotetext{
1 On this issue as on the other issues concerning the strategy of the Four Pillars, references and bibliographies are available in the Information Letters ("The Four Pillars - Les Quatre Piliers", Information Bulletin issued by the Geneva Association. See in particular No. 5 (May 1988), No. 6 (December 1988), No. 7 (August 1989).
} 


\section{Social security, savings and the "Social-Intergenerational" contract}

When, in the course of the last century, the first social security schemes were organized, they did provide a retirement pension at an age at which the average population was already supposed to be dead. Such schemes therefore only protected those who had the chance to survive beyond their statistical life expectancy.

Today, we have already noticed that at the age of 60 , life expectancy is approaching in the average 20 years of age.

As a consequence, the so-called dependency rate which measures the number of active people for the number of retired ones will, right after the year 2000 , create quite a new situation.

Whereas today, in most industrialized countries, there are about 3 active persons for one retired, trends are pointed in such a direction that for instance, in Germany, forty years from now there would be one active person for one person retired under present conditions of employment and of retirement schemes.

We have in fact up to the end of the century to reorganize and modify a system which for the time being is benefitting from the "middle-aging" of the baby-boom.

Such considerations are to be integrated into the wider scope of the "Life Cycle Economic Theory". ${ }^{2}$

We can just mention in this context the important issue of bequests and the effect of the distribution of wealth of people during their life cycle.

It appears that in the present situation, people in the second part of their active life benefit both from higher salaries as well as from other accumulated resources (such as bequests) which become available later and later. It would seem obvious that if, in these conditions, older people still continue to be requested to retire earlier and the cost of such earlier retirement should be supported by a diminishing younger population, the implicit social "inter-generational contract" is at danger of being broken at some point.

In addition, it is a reasonable hypothesis, to be tested in more and more specific cases, that the substitution of older workers by young workers, for the same type of job, is less and less obvious and possible.

Although we have witnessed until now, in most industrialized countries, a tendency to an earlier and earlier retirement, evidence seems to accumulate that this trend is being reversed both at the level of attitudes, practices as well as of the legislations.

This is why the Geneva Association has already started since 1985 to study the hypothesis that in the new Service Economy, a more adequate social policy will be based on the strategy of the "Four Pillars" consisting of:

${ }^{2}$ See for instance "Life Cycle Theory", by Franco Modigliani as well as "Social Security, Pensions and Life Cycle Accumulation of Wealth: Some Empirical Tests", by Edward Wolf in "Etudes \& Dossiers" No. 102, August 1986 of the Geneva Association. These two papers are a selection of a series of other papers on the same subject presented at the International Seminar on Life Cycle Theory, Paris, 4-5 June, 1986, organized by Prof. Denis Kessler and published in the "Annales d'Economie et de Statistiques" No. 9, January/March 1988, special issue on "La Théorie du Cycle de Vie", Paris. See also the study by $D$. Kessler in this issue. 
a) A basic social security scheme, guaranteed and managed by public institutions to cover a minimum level of financial survival.

b) A complementary pension scheme, linked to the employment activity, normally organized on a capitalization basis and made compulsory by state regulations even if managed by private institutions.

c) Personal accumulations through savings as well as bequests.

d) The possibility to complement such sources of income through (mainly) a part-time job. ${ }^{3}$

Part-time employment coupled with partial pensions is now a scheme existing in all the European Nordic countries. Germany has just prepared a law going in this direction and confirming the study of the Geneva Association on "Prolonged Lifetime Employment and a Flexible Transition from Labour Force Participation to Retirement", which we reproduce in this issue.

It has to be noticed that this trend is accompanied also by the one which puts men and women at the same level as to the retirement age. In fact, one must also notice that women's life expectancy normally has become more and more favourable as compared to men in the most developed countries. Another trend to be observed is the elimination of any mandatory limit for retirement.

\section{The ability and capacity to work at any age}

During the industrial revolution, larger and larger parts of the population have been more and more segregated: the work of women at home has been considered less and less "productive" as the essential activity was the remunerated one by men in the industrial process. Young people had to enter the practice of an active life later and later as compared to any other period in history. At an age when Alexander the Great had already conquered his Empire, most young men today are still struggling through their first years of university. And finally the older people, although in the last few decades richer and richer for the majority of them, have been more and more marginalized. This process is of course also being accompanied by a situation in which a part of the older people still cannot get enough financial resources; they had created a small but consistent percentage of the poor and destitute population. The problem here is therefore essentially one of redistribution within the same age group, rather than of general loss of wealth because of aging.

Culturally, we have passed through different phases: first of all, during the agricultural age of society, older people were considered as wise ones and did conserve power and ability to be active. During the industrial revolution, the notion and practical experience of obsolescence has spread from machines and tools to people: therefore, the older people have become more and more marginalized. In the new service economy, where the problems of obsolescence of course exist, but where work can be flexible, reduced in time, and where experience coupled with continuous programmes of updating and education is becoming recognized, the older person seems to be at the beginning of a period at which he regains the possibility to reintegrate society and play the role of an active member.

Both scientific studies and prejudices seem to change. On the biological side, more and more articles are being published showing the possibility of regeneration of neurons and brain cells at an older age than supposed until 20 years ago. On the prejudice's side, a

\footnotetext{
${ }^{3}$ Also on these issues, see the information in the Newsletter "The Four Pillars".
} 
new wave seems to be in the making whereas the "older", thanks to its motivation and enthusiasm to prove that he is still alive and productive, is presented sometimes as a "work horse" ${ }^{4}$ Attitudes seem to change rather quickly also at the front of the trade unions as well as of the employers. It is the market itself which is pushing in this direction: employers who would like to benefit from the experience of older and qualified people who can be available only on a part-time basis, whereas the trade unions face the fact that the majority of their members are of an older age and that a large part are already retired. ${ }^{5}$

An interesting première on this issue is the study by Amin Rajan presented at the end of this publication.

\section{The treatment of sickness and injury and the "capacity" to work or to have a productive activity}

All the above issues provide a ground for important changes in the way money is accumulated through public and/or private savings and is consumed. All financial as well as all productive activities are going to be affected.

In addition, big changes are on the forefront concerning health schemes, leisure time schemes and a combination of the two.

The notion of capacity to work or to have a productive activity will undergo a critical change: today somebody who is by a traditional scheme physically handicapped can become a good computer programmer, whereas somebody who is an athlete might be computer illiterate or otherwise. Education, level of health, experience and psychological attitudes combine more and more to give to the idea of "capacity" quite a new connotation.

It also appears that the possibility to integrate the older in an activity, possibly parttime, is having considerable effect on the health level and even on the rate of absenteeism. ${ }^{6}$

From a societal, an economic and even an ethical point of view, the greatest problem here is already the one concerning health expenses and infrastructures which are necessary for the last year of one's life, during which health costs are equivalent or even superior to the costs accumulated during the rest of the entire life.

In any case, the frontiers in economic and social development are today open: it is the new land of a service society for a Humankind having a much longer life cycle than in the past and introducing as full citizens and active members of the community a population of "over sixties", of whom most likely the great majority of the readers of this issue will be part of, as one billion other people, about 30 years from now.

\footnotetext{
${ }^{4}$ See on this point the very practical experiences developed by the travel insurance companies in the United States: "Integrating the Elder into the Labour Force: Consequences and Experience for Insurance" by Peter Libassi, Geneva Papers No. 49, October 1988. See also "Private Sector Impact of an Aging Society", Etudes \& Dossiers No. 115, September 1987, The Geneva Association.

${ }^{5}$ See in particular No. 6 and 7 of "The Four Pillars" on such issues.

${ }^{6}$ See the No. 5 of "The Four Pillars" and in particular the reference to the situation in Sweden as to the schemes combining partial employment and retirement, which seems to lead to a reduction of absenteeism.
} 